PART 5

Conflict and Control 
Stefano Dall'Aglio - 9789004375871

Downloaded from Brill.com04/26/2023 01:20:33AM via free access 


\title{
Domestic Prayers and Miracles in Renaissance Italy: The Case of Savonarola and His Cult
}

\author{
Stefano Dall'Aglio
}

On 26 August 1583 a long and alarming-sounding letter was making its way through Florence, sent by the city's leading prelate, Archbishop Alessandro de' Medici, to its main political authority, the Grand-Duke of Tuscany Francesco I de' Medici. With respect to the cult of Girolamo Savonarola, the Dominican friar who had been hanged and burned at the stake in Florence in 1498, the archbishop observed: 'si fanno delle conventicole per le case' (they hold conventicles in houses). ${ }^{1}$ Alessandro de' Medici was referring to the Florentine laypeople who were gathering in private homes to venerate Savonarola. His remark tells us that, nearly one century after Savonarola's death, the cult of the friar was still alive and that it was being practised in private households and not in public.

This essay examines the domestic cult of Savonarola and aims at providing a concise answer to a set of crucial questions: did domestic devotion to Savonarola really exist and if so in what did it consist? Why was it domestic? How reliable are the hagiographic sources that document it? How did political and religious authorities react to it? How did Savonarola's followers manage to preserve it? How does it fit into the larger picture of Counter-Reformation Italy? Answering these questions will also help us to understand why the domestic cult of Savonarola continued throughout the sixteenth century, unlike his public veneration.

To begin with, we need to grasp the nature of Savonarola's domestic cult. In the same letter of 1583 , with reference to both lay and religious people, the archbishop gave a detailed description of these conventicles:

occultamente gli fanno l'offizio come a martire, conservano le sue reliquie come se santo fusse, insino a quello stilo dove fu appiccato, i ferri che lo sostennero, li abiti, i cappucci, le ossa che avanzarono al fuoco, le ceneri, il cilicio; conservano vino benedetto da lui, lo danno agli infermi,

1 Letter of Alessandro de' Medici to Francesco I de' Medici, 26 August 1583, in Guasti C., L'officio proprio per fra Girolamo Savonarola e i suoi compagni scritto nel secolo XVI (Prato: 1863) 27.

(C) STEFANO DALL'AGLIO, 2019 | DOI:10.1163/9789004375871_017

This is an open access chapter distributed under the terms of the prevailing CC-BY-NC-ND License at the time of publication. 
ne contano miracoli; le sue immagini fanno in bronzo, in oro, in cammei, in stampa. ${ }^{2}$

From Alessandro de' Medici's account, it was clear that the collections of miracles ascribed to the friar were an essential component of a religious practice that sought to preserve Savonarola's memory as a saint and a martyr. The most important of these is a text known as the Trattato dei miracoli (Treatise of Miracles), a collection of miracles that were attributed to Savonarola's intercession. The Trattato was not the work of a single author: it was compiled during the course of the sixteenth century by various anonymous writers who wished to contribute to the development of a collective memory of Savonarola as a saint who had miraculous powers. This was a process of memory construction whose obvious hagiographical aim was a part of a larger operation aimed at whitewashing Savonarola's image and turning a figure deemed by religious authorities to be a heretic and schismatic into a saint. ${ }^{3}$ Understandably, like many other works on Savonarola penned during the same period, the Trattato was never printed: it was part of a clandestine literary production that could be written, circulated and read only in manuscript. ${ }^{4}$ Printed books needed a formal permission from the Roman Catholic Church authorities and no imprimatur of orthodoxy could be granted to a text that rehabilitated a heretic.

Owing to the unusual way the Trattato was produced, every manuscript copy of the work is different from all the others. The richest one of all, the one with the greatest number of miracles, is the MS Italian 13 in the John Rylands Library in Manchester. ${ }^{5}$ This is a thick volume, written in vernacular Italian

2 Ibid. They secretly celebrate his office as if he were a martyr, they keep his relics as if he were a saint, including the stake from which he was hanged, the iron shackles that supported him, his clothes, his hoods, his bones which were left over from the fire, his ashes, and his cilice. They keep the wine he had consecrated, they give it to the sick, they collect his miracles, they produce portraits of him in bronze, in gold, in cameos, and in print.

3 On the image of Savonarola as a saint and on the attempts to canonise him during the sixteenth century, see Dall'Aglio S., "Everyone Worships fra Girolamo as a Saint': Savonarola's Presumed Sanctity in Sixteenth-Century Manuscripts and Prints", in Frazier A. (ed.), The Saint between Manuscript and Print: Italy 1400-160o (Toronto: 2015) 331-349.

4 The Trattato dei miracoli was printed for the first time in the eighteenth century. The most recent version is in La vita del Beato Ieronimo Savonarola scritta da un anonimo del sec. XVI e già attribuita a fra Pacifico Burlamacchi, ed. P. Ginori Conti (Florence: 1937) 199-249. On the Trattato, see Benavent J., "El Tratado de milagros de fra Girolamo Savonarola. El códice de Valencia y la tradición manuscrita”, Memorie domenicane 28 n.s. (1997) 7-146. On miracle narratives in the same context, see Laven M., "Recording Miracles in Renaissance Italy", in Corens L. - Peters K. - Walsham A. (eds.), The Social History of the Archive: Record-Keeping in Early Modern Europe, Past and Present 230, Suppl. 11 (2016) 191-212.

5 See Benavent, "El Tratado" 32. On this manuscript, see $5^{8-78 .}$ 
in the sixteenth century in a clear hand, though poorly preserved. It contains more than one hundred miracles, the most recent of which dates to 1578 . In it, there are many accounts that cannot be found in any other version of the work. Many speak of a devotion to Savonarola that was practised in private households. The stories and people vary, but they all have this in common: in each narrative a miracle occurs after Savonarola (or one of his fellow martyrs) has been invoked and worshipped by some man or woman in dire circumstances.

Such is the story of the sculptor Bartolo da Montelupo, who had been poisoned in Bologna in the house of a Canon of the local Cathedral. He lay bedridden for six months growing thin and weak, at which point he prayed to the late Savonarola who appeared to him. The friar instructed Bartolo to get up and leave the house, which he did; and from that moment he found that he was perfectly cured. ${ }^{6}$ Then there is the story of a semi-paralysed Florentine woman named Cassandra Acciaiuoli. After languishing in bed at home for a long time, one day she prayed to the 'three friars' - Savonarola and the two fellow-friars who had been executed with him in 1498. No sooner had she concluded her prayer than she suddenly felt better, her legs came back to life, and she was able to stand up and walk again. ${ }^{7}$ These are just two examples of a huge number of miracles performed with Savonarola's intercession for the benefit of private citizens who had prayed and sought help from him in their own homes.

Quite surprisingly, the household might conceal different kinds of objects that could be used, if needed, to obtain a miracle from Savonarola. The wife of Paolo degli Albizzi was healed by a piece of Savonarola's cowl which she conveniently kept in a trunk, ${ }^{8}$ while another Florentine woman, very seriously ill, immediately recovered after taking in her hand a portrait of Savonarola she owned. ${ }^{9}$ This may imply that the devotion to Savonarola did not only exist in time of need: relics and portraits were often kept in the houses of the Florentines and other people, just as today portraits or devotional objects of official saints may still be found in many Italian households. And the domestic devotion of another sick woman, Fiammetta Martelli, appears to have been even more structured, since her bedroom was organised as a sacred space. Afflicted by an incurable disease of the throat, in 1565 she promptly got better

6 Manchester, John Rylands Library (hereafter JRLM), MS Italian 13, fols. 86r-87r.

7 Ibid., fols. 94v-95r.

8 Ibid., fol. 148r.

9 Ibid., fol. 148v. On portraits of Savonarola, see Sebregondi L., Iconografia di Girolamo Savonarola 1495-1998 (Florence: 2004). On miraculous images in the Italian Renaissance, see Holmes M., The Miraculous Image in Renaissance Florence (New Haven - London: 2013) and Garnett J. - Rosser G., Spectacular Miracles. Transforming Images in Italy from the Renaissance to the Present (London: 2013). 
after reading a biography of Savonarola, placing a relic of the friar on her diseased body part, and praying to him at a small altar in her bedroom. ${ }^{10}$

In the case of Carlo Pitti - suffering from a painful illness in his leg in Florence in 1508 - we also have the text of the Latin prayer he recited in his room while holding a fragment of Savonarola's flesh, before recovering and being able to walk again. ${ }^{11}$ In the Trattato, invoking Savonarola clearly ran counter to more traditional medical methods. In fact, a certain Iacopo Lancillotti positively refused to take his doctor's prescription and preferred to pray to Savonarola, upon which he was immediately healed. ${ }^{12}$ And sometimes devotion did not end with the recovery, as in the case of the Ferrarese Pellegrino Depedai. In commemoration of his miraculous healing, every week, on the same day, Depedai lit a candle in front of a portrait of Savonarola he kept at home. ${ }^{13}$ It is also interesting that apparently the domestic cult to Savonarola was not confined to Italy: the Trattato dei miracoli also tells of a priest healed in his home in Spain while lying in bed, after he had called on Savonarola who promptly appeared to him. ${ }^{14}$

Most of the accounts contained in the Trattato tell of people lying in bed with a serious, often terminal illness, invoking Savonarola's help to recover. This image calls to mind countless Italian ex-voto tablets: votive panels that were common in Renaissance Italy and were produced to thank the religious figure responsible for a miracle and preserve and transmit the memory of the event. ${ }^{15}$ In these tablets the scene is often centred on the sickbed, which plays a very important role in the creation of a sacred space. Unfortunately, no votive panel is known for Savonarola's miracles, which is not surprising considering that he was an illegal saint whose cult had been forbidden. Ex-votos were made to be displayed at shrines and were much less easy to produce, reproduce, hide, and circulate than a manuscript volume.

Apart from the traditional healing of ill people lying in bed, other kinds of miracles exist in the Trattato, including a debtor obtaining a deferral for his payment and even a rotten and fetid wine transformed into an exquisite drink that smelt of violets. Savonarola's miracles thus seemed to extend far beyond the domain of healing, and to encompass a wide range of practical problems that the faithful needed to solve. The more inexplicable the outcome, the more it could be ascribed to supernatural intervention and the more Savonarola's authority was enhanced. The picture drawn by the narratives in the Trattato

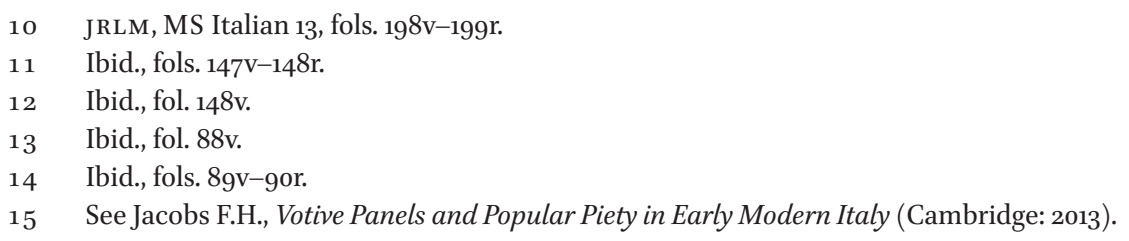


is one of a widespread devotion that was not limited to Florence, Tuscany or Italy, practised by both lay people and clerics, men and women, nobles and people of humble rank.

The accounts contained in the Trattato dei miracoli and in sources like it, such as biographies and hagiographic narratives written by Savonarola's many followers, ${ }^{16}$ raise a question of trustworthiness that cannot be ignored. They certainly tell us much about popular culture and popular narratives, but to what extent can they be regarded as historical sources? What needs to be determined here is the reliability of the first part of the story, not the second: not the account of the supernatural event but of the report that people would invoke Savonarola's help when they were ill in bed or in some other trouble. In other words: did devotion to Savonarola really exist in sixteenth-century Italy or was it the creation of the hagiographers who were seeking to build up the myth of the late friar? I argue that the Trattato's narratives stem from a true historical fact: devotion to Savonarola really existed, was well known inside and outside Florence, and was an integral feature of early modern Tuscan piety. In addition to the Trattato, a hagiographical work that was clearly inspired by Savonarolan propaganda, the existence of a Savonarolan cult is attested by other types of sources, such as letters, ordinances, chronicles, writings, liturgical texts, and even relics.

Obviously, it is more difficult to find direct testimonies of private and intimate devotions than of cults openly performed in public places in front of hundreds of people, such as celebrations in churches or processions. This could have led to an underestimation of a phenomenon that was not only confined to the home but was also practised clandestinely. That said, even public documents can provide some useful evidence. Many of them are indirect testimonies, produced by worried religious and civic authorities who wished to suppress the Savonarolan cult, such as Archbishop Alessandro de' Medici's letter cited at the beginning of this essay. The very existence of these concerns is itself a demonstration that the cult existed and was largely practised, or nobody would have felt the need to intervene.

The ordinances against the cult of Savonarola in convents and private homes commenced long before 1583 . Indeed, as early as February 1499, less than a year after the friar's execution in May 1498, Francesco Mei, Procurator of the Dominican order, issued an ordinance banning any conversation about Savonarola and his prophecies, the possession of the three friars' relics (bones, hair, fragments of skin, pieces of wood taken from the scaffold) and those of

16 See, for example, Pico della Mirandola Giovanni, Vita di Hieronimo Savonarola (Volgarizzamento anonimo), ed. R. Castagnola (Florence: 1998) 73-89. 
anybody else who was not canonised by the Church. It also prohibited the exposition of Savonarola's prophecy both in public and private ('in publico vel private'). ${ }^{17}$ A later offensive, which did not concern only the Dominican order, was launched in 1515. In that year, Giulio de' Medici, vicar of the Florentine archbishop and future pope Clement VII, issued a new ordinance against Savonarolan devotion: anyone who harboured in his house ashes, bones, teeth, portraits, imprints, other relics or writings of the friar must turn them in to the vicar of the archbishop or face punishment. ${ }^{18}$ In 1545 the duke of Florence, Cosimo I de' Medici, himself took action and even accused the friars of San Marco of idolatrous veneration of Savonarola, and promoting his worship as a saint. ${ }^{19}$

Contrary to what one might think, after forty years the problem had not gone away. Apparently, friars and lay citizens still had the unseemly habit of evoking Savonarola's miracles, and their cells and households were still cluttered with objects associated with him. In 1585, not long after Alessandro de' Medici's concerned letter to the Grand-Duke, the head of the Dominican order acted again, as his predecessor had done in 1499. The fact that the new ordinance's content is almost the word for word copy of the old one is the best demonstration that the devotion still existed. In much the same way as Francesco Mei had done, Sisto Fabbri, Master General of the order, commanded as follows:

niuno o niuna habbi ardire di nominare, con frati o monache o secolari, il nome di fra Gerolamo Savonarola, con trattare della sua vita o soi miracoli, o delle cose sue o suoi compagni in qualsivoglia modo, né tenere appresso di sé ritratti, immagini o cose di qualsivoglia sorte [...]. Ordinando [...] che fra il termine d'un giorno debbano presentare tutte le cose simili. ${ }^{20}$

That the above mentioned objects were being used for the purposes of an illicit devotion and not for the harmless preservation of the friar's memory clearly emerges in another passage of the same ordinance which refers to an

\footnotetext{
17 Ordinance of Francesco Mei, 3 February 1499, in Gherardi A., Nuovi documenti e studi intorno a Girolamo Savonarola (Florence: 1887) 329-330.

18 Parenti P., Istorie fiorentine, in Schnitzer J., Quellen und Forschungen zur Geschichte Savonarolas, vol. 4 (Leipzig: 1910) 307.

19 Gherardi, Nuovi documenti 344.

20 Ordinance of Sisto Fabbri, 5 April 1585, ibid., 351. Nobody must dare to name the name of Girolamo Savonarola when dealing with friars, nuns or lay people, to discuss his life or his miracles, or him and his companions in any way, or keep his portraits, pictures or any kind of object $[\ldots]$. We order $[\ldots]$ that all such objects are to be handed over within one day.
} 
earlier unheeded decree prescribing that only people officially canonised by the Church could be venerated, and not those who had been condemned. ${ }^{21}$

Formal ordinances issued by the authorities are not the only testimonies of the domestic cult of Savonarola. Sometimes convent chronicles mention friars and nuns praying to Savonarola in their own cells. ${ }^{22}$ The works written for and against the friar during the sixteenth century also tell us that private homes in and outside Florence were occasionally transformed into sacred spaces to worship Savonarola. Both defenders and opponents agreed that a cult of Savonarola existed. The former saw it as evidence of the spiritual fascination a true prophet exerted over a number of faithful, the latter as proof of the deception he had intentionally perpetrated on his naïve followers. The most interesting testimony is undoubtedly that of the Dominican bishop Ambrogio Catarino Politi, a controversialist who turned against Savonarola after being one of his staunchest supporters. ${ }^{23}$ As such, he was in a privileged position to know even the most secret practices of the friar's followers. In his Discorso contra fra Girolamo Savonarola (1548), printed exactly fifty years after Savonarola's execution, he painted a vivid picture of the way Savonarola's followers still venerated the late friar:

non dovrebbono superstitiosamente adorarlo, come molti di loro so certo che facevano et ancor non cessano di fare, et tengono o dipinta o scolpita la imagine sua con lettere che dicono 'Profeta et Martire'. Sono anchora altri che tengono della cenere o altre cose di lui et le venerano come reliquie sante. ${ }^{24}$

As if this were not enough, Catarino also went to the trouble of offering advice to the authorities in order to show them the way to eradicate the cult of Savonarola: 'commandare strettamente che $[. .$.$] niuno havesse ardimento di$ farli alcuna veneratione, et prohibire tutte le conventicole le quali intendo farsi

21 Ibid., 350 .

22 See, for example, Di Agresti D., Sviluppi della riforma monastica savonaroliana (Florence: 1980) 181. On the Savonarolan cult in female religious communities in Northern Italy, see Herzig T., Savonarola's Women. Visions and Reform in Renaissance Italy (Chicago: 2008).

23 On him, see now Caravale G., Beyond the Inquisition. Ambrogio Catarino Politi and the Origins of the Counter-Reformation, transl. D. Weinstein (Notre Dame, IN: 2017).

24 Politi Ambrogio Catarino, Discorso contra la dottrina et le profetie di fra Girolamo Savonarola (Venice, Gabriele Giolito: 1548) fol. 18r. They should not superstitiously worship him, as I know for sure many of them are wont to do and persist in doing. And they keep his painted or sculpted image with letters that read 'Prophet and Martyr'. There are even others who keep his ashes or some other things of his and venerate them as holy relics. 
da più persone, dove si fanno sacrifici et orationi communi a fra Girolamo'25 ('strictly to order that nobody should dare to venerate him [Savonarola] in any way, and to forbid all the conventicles which I heard are held, where sacrifices and group prayers to fra Girolamo are made').

Another important source are the Divine Offices composed in the sixteenth and seventeenth centuries for the purpose of praying to Savonarola. At least one of these was certainly composed during the papacy of Clement viII Aldobrandini (1592-1605), when Savonarola's followers thought that the time had finally come for him to be canonised. These texts were meant to be recited on the anniversary of Savonarola's death (23 May) and inserted into the Roman Breviary. The offices are divided into parts to be prayed at different times of the day, and their structure - including psalms and hymns, antiphons and responsories - follows the traditional Catholic Liturgy of the Hours. The texts contain invocations to 'Beatus Hieronymus' ('Blessed Girolamo') and 'Sanctus Martyr Hieronymus' ('Saint Martyr Girolamo') and a long part is devoted to the description of Savonarola's life from his childhood to his death. ${ }^{26}$ We do not know exactly when, where and by whom they were recited orally, but we may suppose that this is the sort of 'office' to which Archbishop Alessandro de' Medici was referring in his letter ('they secretly celebrate an office in his honour as if he were a martyr').

The picture is completed by material sources: alleged relics of Savonarola are currently housed in the Convent of San Marco in Florence, the very place where Savonarola spent all his years in the city: a cowl, a rosary, a wooden fragment of the scaffold, two cilices and a piece of cloth. ${ }^{27}$ Obviously there is no way of assessing whether these objects were actually linked with the friar himself. Most were donated to the convent in 1686, almost two centuries after his demise. However, their importance clearly goes well beyond whether they can be reliably attributed. ${ }^{28}$ Regardless of the links tracing them back to Savonarola, we know that relics like these existed and were an integral feature of the domestic devotion to Savonarola in households and convent cells.

Having ascertained that domestic devotion to Savonarola existed, the next question that arises is why this devotion was domestic. The most obvious

\footnotetext{
25 Ibid., fol. 22 r.

26 The texts of the offices can be found in Guasti, L'officio proprio $35^{-48}$ and Gherardi, Nuovi documenti $35^{8-364}$.

27 Rasario G., "Savonarola e le sue 'reliquie' a San Marco", in Scudieri M. - Rasario G. (eds.) Savonarola e le sue 'reliquie' a San Marco (Florence: 1998) 52-59.

28 On the significance of relics, see Walsham A., "Introduction: Relics and Remains", Past \& Present 206, Suppl. 5 (2010) 9-36. On the cult of Savonarola's relics, see Benavent J., "Las reliquias de fra Girolamo Savonarola" Memorie domenicane 29 n.s. (1998) 159-177.
} 
answer is that, being prohibited, the Savonarolan cult could not be practised in public places. With the exception of the years 1527-1530, when a popular, anti-Medici republic was reintroduced in Florence and public celebrations in honour of Savonarola flourished, the cult of the friar was unwelcome not only to the Florentine government but also to religious authorities in and outside the Dominican order. ${ }^{29}$ Another possible answer focuses on a more intimate and private side of devotion to Savonarola. We know that in the Savonarolan years the friar promoted theatrical and collective celebrations, not only public processions but spectacles performed in public squares before huge crowds, such as the bonfire of the vanities or the trial by fire. Nevertheless, alongside this sensational and public devotion a different kind of piety developed, one that was characterised by solitude and meditation. After all, Savonarola himself emphasised the primacy of mental over vocal prayer. ${ }^{30}$

Most importantly, Savonarola explicitly encouraged the practice of domestic devotion among late fifteenth-century Florentines. In one of his sermons, delivered in the Florentine cathedral in Lent 1496, the friar set out the programme of a liturgy to be recited in every home each evening and morning by all the members of the family, regardless of gender, age, or social status:

Voi padri di famiglia ordinate che a ventiquattro ore sabbato sera tutti siate in casa con la vostra famiglia, e poi ve n'andate tutti, uomini, donne, fanciulli, servi e serve in luogo di casa vostra, e quivi ginocchioni direte li sette salmi e le letanie [...]. Dipoi a mattutino [...] sarà buono che vi raguniate una altra volta in quel medesimo luogo, il messere e la madonna con li figliuoli intorno e li servi e serve, e diciate el mattutino della Madonna. $^{31}$

His words did not go unheeded if we are to believe one of his hagiographers who (with clear exaggeration), observed that the kind of life Florentines led in the privacy of their homes was no different from that of churchmen: 'Nelle

29 On Savonarolan resurgence in the period 1527-30, see Polizzotto L., The Elect Nation. The Savonarolan Movement in Florence 1494-1530 (Oxford: 1994) 334-382.

30 See Caravale G., Forbidden Prayer. Church Censorship and Devotional Literature in Renaissance Italy (Farnham: 2011) 5-12.

31 Savonarola G., Prediche sopra Amos e Zaccaria, 3 vols., ed. P. Ghiglieri (Rome: 1971-72) vol. 3, 234-235. You, fathers, must order that at twenty-four hours on Saturday evening everybody should be at home with your family, and then all of you, men, women, children and servants shall go to a place in your house and here on your knees you shall recite the seven psalms and the litanies [...]. And then in the morning [...] it will be good that you gather again in the same place, the master and the lady with the children around and the servants, and recite matins for the Virgin. 
lor case erano diventati et vivevano come frati et religiosi, et di molte nobili persone, levandosi al mattutino nelle lor case, et di dì, celebravano il divino

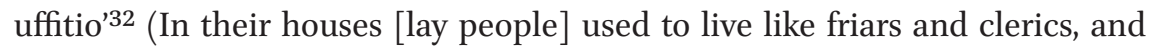
many noble people, waking up in the morning in their houses, and during the day, used to celebrate the divine office). I argue that after Savonarola's death the domestic devotion he had inspired contributed to nourishing a domestic cult devoted to the man himself. This was the consequence of the political and religious climate - the cult of Savonarola was forbidden - but also of a shift away from shared prayer to solitary devotions, which fits in well with the more intimate side of the Counter Reformation, characterised by private rather than public meditation.

At the end of the sixteenth century another Dominican friar, Serafino Razzi, led the way to the revision of the Counter-Reformation approach to domestic devotion to Savonarola. In 1598 he took the trouble of replying to his fellowfriar Ambrogio Catarino Politi who, as we have seen, had violently attacked Savonarola's devotees. Contrary to what one may think, Razzi made no attempt to deny that many followers were still venerating the friar in their own houses or their own cells. After all, Savonarola had been sentenced as a heretic, and it would hardly be possible to worship him while submitting to the Roman Catholic Church, one of the two authorities that had contributed to his own condemnation. In spite of that, Razzi claimed the right to venerate Savonarola in private:

Beatum eum esse sacri canones non negant, quemadmodum nec prohibent eorum cineres pie servare, alioqui multo sanctorum corpora deperiissent si ante illorum solemnem canonizationem servata cum honore non fuissent $[\ldots]$ At si quis privatim pro sua devotione velit eum colere $[\ldots]$ qui mali est? ${ }^{33}$

$32 \quad$ La vita del beato Ieronimo 88. See also 95. More generally, on domestic devotion in early modern Florence, see Ciappelli G., Memory, Family, and Self. Tuscan Family Books and Other European Egodocuments (14th-18th Century) (Leiden - Boston: 2014) 82-108.

33 Razzi Serafino, Brevi risposte alle oppugnazioni di frate Ambrogio Politi Catarino contra la dottrina e contra le profezie del padre fra Ieronimo Savonarola, Florence, Biblioteca Nazionale Centrale, MS Palatino 906, fols. $1 \mathrm{r}-43 \mathrm{r}$ (fols. 18r and 19v). Sacred canons do not deny he [Savonarola] is Blessed, and likewise they do not prohibit the devout preservation of his ashes. Otherwise, the bodies of many saints would have deteriorated if they had not been respectfully preserved before their solemn canonisation [...] After all, what is wrong with somebody wanting to worship him [Savonarola] privately for his own devotion? 
In addition, Razzi wrote in another work: 'Et questa venerazione [...] tenghiamo appresso di noi privatamente et appresso a Dio [...] con speranza ancora che, quando che sia, per ordine della Santa Chiesa cattolica romana [...] egli [Savonarola] habbia da essere canonizato'34 ('We keep this veneration [...] with us, privately, and with God [...] in the hope that one day, at the order of the Holy Roman Catholic Church, [...] he [Savonarola] will be canonised'). In short, Razzi claimed the right to a domestic devotion to Savonarola in spite of the friar's condemnation, as if private devotion should not only be accepted de facto but recognised de jure. As if everybody, inside his own household, should be free to pray to and worship whomever he wanted, including a man condemned as a heretic.

If this sounds odd, and in open contradiction with the Counter Reformation's control over the private sphere, it is worth mentioning the decree that the Congregation of the Holy Office issued only three years later, in September 1601. The decree prohibited only public unauthorised prayers, and this meant that the Church surrendered control over the private devotion. ${ }^{35} \mathrm{~A}$ confirmation of this compromise which was implied in the 1601 decree arrived, shortly after, from Giovanni Paolo Mucanzio, secretary of the Sacred Congregation of the Rites, the Catholic Church's body responsible for the liturgical cult and canonisations. When asked about the legitimacy of the cult of a non-canonised person, he answered: 'il culto e venerazione pubblica [...] non si può né deve dare a nessuno senza licenza o autorità della Sede Apostolica $[. .$.$] ma$ la privata divozione e venerazione non si può togliere né levare a nessuno'36 ('public cult and veneration [...] cannot be given to anybody without licence or authorisation of the Apostolic See [...] but private devotion and veneration cannot be denied to anybody'). The same answer was also given by one of the most powerful and authoritative theologians of Counter-Reformation Italy, Cardinal Roberto Bellarmino: 'an liceat colere non canonizatum, rispondeo licere private cultu, non publico [...] Licet invocare non canonizatum [...] at non liceret in publiciis litaniis'37 ('whether it is permitted to venerate a noncanonised person, I answer that the private cult is permitted, but not the public one $[\ldots]$ It is permitted to invoke a non-canonised person [...] but not in public litanies'). A manual for inquisitors composed a few years later refers to

34 Razzi Serafino, Defensione della dottrina, delle profezie e della santità del padre fra Girolamo Savonarola, ibid. fols. 45r-64r (63v-64r).

35 Caravale, Forbidden Prayer 181-183. See also 241-243.

36 Benedictus XIv, Opera in duodecim tomos distribuita vol. 2 (De servorum Dei beatificatione et beatorum canonizatione) (Rome, Nicola e Marco Pagliarini: 1747) 181.

37 Bellarmino Roberto, Disputationum de controversiis christianae fidei adversus huius temporis haereticos vol. 2 (Venice, Giovanni Malachino: 1721) 356. 
the 1601 decree and confirms that toleration towards the private sphere had been assimilated in everyday practice. In his Sacrum tribunal printed in Rome in 1648, the inquisitor and theologian Francesco Bordoni explained that the faithful were allowed privately to venerate people who had not been officially canonised by the Church: 'Privatim et occulte in propriis necessitatibus invocari et venerare possunt, quia in decreto prohibetur solum cultus publicus' 38 ('They may invoke and worship [them] in their needs in private and secretly, because the decree forbids only public cults').

The insistence on the word 'private' in all the passages above, and my implicitly equating it with the term 'domestic' calls for a semantic clarification. One may think that the private cult refers to the interior dimension of prayer instead of the actual physical space where prayer was conducted, just like Savonarola's distinction between mental and vocal orations. This is not what was meant, as was made quite clear by the theologian Felice Contelori in one of the major treatises of the time on canonisation, the Tractatus et praxis de canonizatione sanctorum, published in 1634. According to Contelori, place is the first criterion to distinguish a public from a private cult: a public cult is one held in a public place. ${ }^{39} \mathrm{~A}$ few decades later another work was even more explicit: in private homes people were allowed to venerate the portrait of a noncanonised person, 'quia est cultus privatus' ${ }^{40}$ ('because this is a private cult'). There can be no doubt that the 'private' devotion referred to by Mucanzio, Bellarmino and Bordoni was the same thing as the 'domestic' devotion practised in a household, a convent cell, or another private place. And, most importantly, this was the private devotion that Razzi claimed for his Savonarolan spirituality, and that in the same years the Congregation of the Holy Office renounced control over.

This surrender of control over private devotion certainly comes as a surprise, in view of the fact this was an age when the Inquisition strove to intervene in a number of non-religious aspects of domestic everyday life, such as superstition, fasting, swearing and concubinage. But prayer was something different, and this compromise ultimately allowed a dual practice to emerge, creating the conditions in which certain devotions were prohibited in public but permitted in private spaces. Clearly this is a far cry from the ordinance issued

38 Bordoni Francesco, Sacrum tribunal iudicum in causis sanctae fidei contra haereticos et de haeresi suspectos (Rome, Heirs of Corbelletti: 1648) 300.

39 Contelori Felice, Tractatus et praxis de canonizatione sanctorum (Lyon, Laurent Durand: 1634) 244. Same interpretation in Scacchi Francesco Fortunato, De cultu et veneratione servorum dei liber primus (Rome, ex typographia Vitalis Mascardi: 1639) 749, and others. 
by the Procurator of the Dominican order at the end of the fifteenth century, which sought simply to repress devotion to Savonarola 'in publico vel private'.

The cult of Savonarola was certainly part of the processes known as the 'domestication of the holy' and the 'spiritualization of the household' which have ignited recent scholarly discussions, and not only with reference to Italy. ${ }^{41}$ After the Counter-Reformation, these processes involved the transfer of holy objects from sacred places into the household and, as a consequence, the sanctification of domestic space. ${ }^{42}$ The transfer of cults into private space clearly might allow the faithful to elude the control of Church authorities that oversaw the forms and contents of religious practice. It is not surprising that some centuries earlier the Carolingian Church conducted the process in reverse and transferred relics and the cults surrounding them from households to monasteries in order to bring them under institutional control. ${ }^{43}$ In the sixteenth century the household could be a place of dissent, opposition and resistance to the official religion imposed by the state. ${ }^{44}$ With specific reference to early modern Italy, John Bossy observed that 'the Counter-Reformation hierarchy seems to have taken it for granted that household religion was a seed-bed of subversion'.45 Duke Cosimo I and Archbishop Alessandro de' Medici must have thought the same about the domestic devotion to Savonarola in Florentine houses and convents, but events would soon demonstrate that the friar's legacy was no longer dangerous, neither politically nor religiously ${ }^{46}$ As both the Republican and the Protestant threats had been defused, those few who wished to pray before an image of Savonarola could continue to do so, as long as they kept away from prying eyes.

41 See Walsham A., "Holy Families: The Spiritualization of the Early Modern Household Revisited", in Doran J. - Methuen C. - Walsham A. (eds.), Religion and the Household, Studies in Church History 50 (2014) 122-160.

42 Fairchilds C., "Marketing the Counter-Reformation: Religious Objects and Consumerism in Early Modern France", in Adams C. - Censer J.R. - Graham L.J. (eds.), Visions and Revisions in Eighteenth-Century France (University Park, Penn.: 1997) 31-57 (49).

43 Smith J.M.H., "Material Christianity in the Early Medieval Household", in Religion and the Household 23-46.

44 Perry M.E., "Space of Resistance, Site of Betrayal: Morisco Homes in Sixteenth-Century Spain", in Howe N. (ed.), Home and Homelessness in the Medieval and Renaissance World (Notre Dame, IN: 2004) 59-9o.

45 Bossy J., "The Counter-Reformation and the People of Catholic Europe", Past \& Present 47 (1970) 51-70.

46 On the transformation of the perception of Savonarola in the second half of the sixteenth century, see Dall'Aglio S., Savonarola and Savonarolism (Toronto: 2010) 139-147. 


\section{Selective Bibliography}

\section{Primary Sources}

Gherardi A., Nuovi documenti e studi intorno a Girolamo Savonarola (Florence: 1887).

Guasti C., L'officio proprio per fra Girolamo Savonarola e i suoi compagni scritto nel secolo XVI (Prato: 1863).

La vita del Beato Ieronimo Savonarola scritta da un anonimo del sec. XVI e già attribuita a fra Pacifico Burlamacchi, ed. P. Ginori Conti (Florence: 1937).

Manchester, John Rylands Library, MS Italian 13.

\section{Secondary Sources}

Benavent J., "Las reliquias de fra Girolamo Savonarola" Memorie domenicane 29 n.s. (1998) 159-177.

Benavent J., "El Tratado de milagros de fra Girolamo Savonarola. El códice de Valencia y la tradición manuscrita", Memorie domenicane 28 n.s. (1997) 7-146.

Caravale G., Forbidden Prayer. Church Censorship and Devotional Literature in Renaissance Italy (Farnham: 2011).

Dall'Aglio S., Savonarola and Savonarolism (Toronto: 2010).

Dall'Aglio S., "Everyone Worships fra Girolamo as a Saint': Savonarola's Presumed Sanctity in Sixteenth-Century Manuscripts and Prints", in Frazier A. (ed.), The Saint between Manuscript and Print: Italy 1400-160o (Toronto: 2015) 331-349.

Polizzotto L., The Elect Nation. The Savonarolan Movement in Florence 1494-1530 (Oxford: 1994). 